Ewa Badyda

Uniwersytet Gdański

fpoeba@ug.edu.pl

\title{
O KŁOPOTACH NAUCZYCIELA Z MATERIAŁEM LEKSYKALNYM PODRĘCZNIKÓW DO NAUCZANIA JĘZYKA POLSKIEGO JAKO OBCEGO - NA WYBRANYCH PRZYKŁADACH
}

\begin{abstract}
Teacher's problems with vocabulary introduced in Polish language coursebooks for foreign students - on the selected cases

The article discusses the problems concerning vocabulary introduced in some popular contemporary coursebooks for Polish language teaching. What can be sometimes found in them are words and expressions not suiting the language level of the course, some of them rare, specialized, obsolete, marked in a characteristic way, regional. It also happens that words are used improperly in the context or they are consolidated in unnatural linguistic contexts. Also some problems with proper names appear - they sometimes have a confusing form or, with no good reason, they are very difficult to pronounce. The situation is partly the result of the authors' efforts made to simplify grammar or introduce humorous atmosphere during the lesson. In the conclusion the author suggests paying more attention to the choice of vocabulary units to be taught.
\end{abstract}

Keywords: Polish as a foreign language, vocabulary, coursebooks

Słowa kluczowe: język polski jako obcy, leksyka, podręczniki

\section{Wprowadzenie}

Słownictwo jest podstawowym budulcem wypowiedzi językowych, jest zatem rzeczą oczywistą, że w nauczaniu języka obcego powinno zajmować miejsce w najściślejszym centrum uwagi. Świadoma koncentracja na tej składowej języka 
należy do założeń współcześnie dziś popularnego komunikacyjnego modelu nauczania. Z punktu widzenia skuteczności komunikacyjnej osoby, która dopiero dąży do pełniejszego opanowania obcego języka, warstwę leksykalną uważa się za ważniejszą niż gramatykę, ponieważ nieznajomość potrzebnego w danej sytuacji słownictwa może całkowicie zablokować przekaz komunikacyjny, podczas gdy gramatyki - tylko go zakłócić bądź zniekształcić (Seretny i Lipińska, 2005: 75-76). Ponieważ słownictwo tak silnie warunkuje skuteczność komunikacyjną, należy dbać o jego staranny dobór z uwzględnieniem przewidywanych potrzeb uczącego się na poszczególnych poziomach zaawansowania językowego. Do namysłu nad zasobem słownictwa wprowadzanym na poszczególnych etapach nauki skłania dodatkowo przeprowadzana obecnie na szerszą skalę standaryzacja nauczania i wymogi związane z certyfikatowym testowaniem języka polskiego jako obcego. Myśląc o nauczaniu języka polskiego w kategoriach poziomów biegłości językowej, odzwierciedlającej kompetencje komunikacyjne studenta, które upowszechniło się dzięki pracom nad tymi obszarami, trzeba unikać wszelkich przypadkowości w doborze jednostek leksykalnych. Dotyczy to zwłaszcza poziomów najniższych, kiedy to student dopiero poznaje język i obdarza dużym zainteresowaniem każdy pojawiający się wyraz, a jednocześnie każdy z nich stanowi stosunkowo duży udział w opanowywanym przez niego zasobie leksykalnym i w konsekwencji w dużym stopniu odpowiada za jego możliwości komunikacyjne ${ }^{1}$. Można też się spodziewać, że wyrazy, z którymi student spotka się na początkowych etapach nauki, w przyszłości będą już przede wszystkim wchodziły w skład jego czynnego słownictwa.

Świadomość wagi doboru słownictwa nie jest obca polskiej myśli glottodydaktycznej, podejmowane już były próby określające treści nauczania w zakresie leksyki języka polskiego jako obcego, ustalenia listy słownictwa podstawowego w oparciu o dane frekwencyjne sporządzane dla poszczególnych odmian języka i tekstów oraz dopełniania pól semantycznych (Seretny i Lipińska 2005: 80-84). Nie zawsze jednak wydają się o takiej trosce świadczyć współczesne podręczniki do nauczania języka polskiego, w których zdarza się napotkać jednostki leksykalne, które w różny sposób sprawiają świadomemu swoich zadań nauczycielowi kłopot, zmuszając go do obszerniejszego komentarza metajęzykowego, metadydaktycznego, uzupełnień wywołanych tylko ich pojawieniem się bądź do decyzji o usunięciu ich z pola uwagi studenta.

W niniejszym artykule chciałabym przedstawić kilka rodzajów takich problemów, na które napotkałam przede wszystkim we własnej praktyce dydaktycznej. Materiał pochodzi z 4 współcześnie używanych podręczników

\footnotetext{
${ }^{1}$ Zakłada się, że osiągnięcie poziomu A2 (podstawowego) wymaga opanowania 1500 słów, poziom B2 (samodzielności językowej) - 5000 (Seretny i Lipińska, 2005: 84).
} 
przeznaczonych dla osób rozpoczynających dopiero naukę języka: Jak to łatwo powiedzieć... Danuty Gałygi, Hurra!!! Po polsku 1 Małgorzaty Małolepszej i Anety Szymkiewicz, Start 1, Survival Polish Kamili Dembińskiej i Agnieszki Małyski oraz Dzień dobry! Aleksandry Janowskiej i Magdaleny Pastuchowej. Najstarszy z nich wydany został w 2006 roku, najnowszy w 2011, dwa z nich miały wydania wcześniejsze, jeden oparty jest na podręczniku wydanym wcześniej pod innym tytułem.

\section{Postulat uniwersalności, aktualności, typowości i przydatności komunikacyjnej słownictwa wprowadzanego w podręcznikach a jego realizacje}

Jednym z kryteriów doboru leksykalnego na poziomie podstawowym powinna być uniwersalność jednostek leksykalnych. W pierwszej kolejności powinno się wprowadzać wyrazy nieograniczone rejestrem stylistycznym, w tym służące opisywaniu desygnatów obecnych we współczesnej rzeczywistości, terminy z kognitywnie rozumianego poziomu podstawowego, a spośród synonimów takie, które mają najczęstszą frekwencję i najmniejsze ograniczenia łączliwości. Ważne jest też, żeby wyrazy pojawiały się w naturalnych kontekstach językowych, pokazujących ich użycie w wypowiedzi. Dotyczy to zwłaszcza tych, które są szczególnie wyeksponowane, na przykład w partiach podręcznika poświęconych właśnie słownictwu.

W podręcznikach do nauki języka polskiego jako obcego na poziomie elementarnym zdarza się nawet w tych miejscach napotkać wyrazy rzadkie, o ograniczonym zasięgu użycia czy nacechowane stylistycznie.

W Jak to powiedzieć... w jednej z lekcji prezentowane są określenia nazywające różne typy mieszkań. Do odpowiednich schematów mieszkania należy dopasować wyrazy/ wyrażenia określające jego typy. Podane określenia to: garsoniera, pokój z aneksem kuchennym, jednopokojowe z jasnq kuchniq, mieszkanie dwupokojowe, M-4 (Gałyga, 2011: 94). Konstrukcja ćwiczenia umożliwia traktowanie podanego zestawu jako odpowiadającego podstawowej kategoryzacji mieszkań, którego opanowanie pozwoli skutecznie wskazywać różniące się od siebie desygnaty w rzeczywistości pozajęzykowej, w sumie - jako mikropole leksykalne, którego znajomość umożliwi studentowi na przykład rozmowę w sprawie wynajęcia mieszkania czy odszukanie odpowiedniego ogłoszenia. A zatem należy go sobie w przyszłości wyobrazić w sytuacji, w której będzie on pytać o garsonierę w przekonaniu, którego nabrał na podstawie rysunku z podręcznika, że tak należy nazwać mieszkanie jednopokojowe z aneksem kuchennym w odróżnieniu od mieszkania jednopokojowego z jasnq kuchniq̨. Uniwersalny słownik języka polskiego (2008) podaje następującą definicję 
garsoniery: „garsoniera przestarz. «mieszkanie kawalerskie; także: mieszkanie należące do mężczyzny, służące do celów towarzyskich «", Inny słownik języka polskiego (2000): „Garsoniera to małe jednopokojowe mieszkanie dla samotnego mężczyzny. Słowo przestarzałe." Słowo to funkcjonuje co prawda jeszcze w znaczeniu neutralnym, ale na pewno jego frekwencja w tym znaczeniu jest zdecydowanie niższa niż kawalerki. O proporcjach przekonują przykładowo dane z działu ogłoszeń dotyczącego nieruchomości najbardziej popularnego trójmiejskiego portalu trójmiasto.pl: wyraz ten użyty został 4 razy, podczas gdy kawalerka 2363. Zdecydowanie obca w znaczeniu neutralnym środowisku wielkomiejskiemu z północy Polski, garsoniera bardziej znana jest w nim na południu Polski, ale nawet w krakowskim internetowym serwisie ogłoszeń na stronie http://www.ogloszenia.krakow.pl/ proporcje te wynoszą 38 dla garsoniery do 117 dla kawalerki. Do jakich więc skojarzeń odwołać się może przeciętny zapytany o garsonierę Polak, w którego słownictwie to przestarzałe słowo już nie funkcjonuje? Mniej może dziś prawdopodobne, że będzie to czytelnik kultowej powieści Choromańskiego, ale niewykluczone, że będzie to internauta znający nazwę jednego z największych chyba polskich sexforów. Skądinąd, jeżeli podane w podręczniku słownictwo miałoby umożliwiać odnoszenie się do pewnych kategorii w rzeczywistości pozajęzykowej i różnicowania pod tym względem jej elementów, trudna do określenia jest też różnica między kawalerkq̨/ garsonierq a mieszkaniem jednopokojowym.

Przejrzenie tego samego trójmiejskiego portalu przekonuje, że popularne niegdyś określenia $M-2, M-3$ czy $M-4$ wychodzą już zupełnie z użycia. Każde z nich pojawiło się w ogłoszeniach tylko po kilkanaście razy, najczęściej w stałych formułach tych samych pośredników biur nieruchomości. Związek tych określeń z realiami konkretnej epoki zauważa też Inny słownik języka polskiego: „M- to skrót słowa „mieszkania”, używany w konstrukcjach M-2, M-3 itp., które zgodnie z normami stosowanymi w PRL oznaczały mieszkanie przeznaczone dla wskazanej liczby osób." Zapytanie o takie mieszkanie osób z młodszego pokolenia stanowi zapewne swoiste ryzyko komunikacyjne: jeżeli rozpoznają one odniesienie użytego zwrotu, mogą nie do końca uświadamiać sobie, że liczba w nazwie nie odpowiada liczbie pokojów w mieszkaniu.

Innego rodzaju kłopot stanowi określenie pokój dziecinny prezentowane w tym samym podręczniku w grupie słownictwa nazywającego pomieszczenia w mieszkaniu (Gałyga, 2011: 97). W języku polskim nośnikiem zróżnicowania semantycznego związanego ze sferą denotacyjną i konotacyjną wyrazu dziecko/ dziecina są dwa derywaty przymiotnikowe. Dziecięcy to 'odnoszący się do dzieci, przeznaczony dla dzieci, charakterystyczny dla dziecka', dziecinny zaś to 'taki, jak u dziecka, właściwy dziecku, tj. naiwny, niepoważny, beztroski'. Znaczenie czysto relacyjne jest dziś dla wyrazu dziecinny znaczeniem 
przestarzałym, chociaż w niektórych kontekstach oba wyrazy mogą być zasadniczo wymienne. Jednak nie na całkowicie równych prawach. Nowy słownik poprawnej polszczyzny PWN podaje następujący przykład tej wymienności i jej ograniczeń: „dziecinny przestarz. «"w odniesieniu do przedmiotów: przeznaczony dla dziecka; dziecięcy»: Dziecinny, częściej: dziecięcy wózek. Dziecinny pokój. Dziecinne, częściej: dziecięce, ubranko. Ale: Szpital dziecięcy (nie: dziecinny). Literatura dziecięca (nie: dziecinna)". Wprowadzając w nauczaniu wyrażenie pokój dziecinny, nie pokój dziecięcy, podaje się więc jako podstawowe określenie takie, które w polszczyźnie ponadregionalnej jest przestarzałe, rzadsze frekwencyjnie ${ }^{2}$. Decyzja ta może mieć jednak dalsze skutki. Dobierając bowiem słownictwo w nauczaniu języka obcego, warto mieć na względzie dalsze możliwości, jakie przed studentem otwiera dana jednostka leksykalna. W tym wypadku może on dla słowa dziecinny samodzielnie zrekonstruować znaczenie 'dla dziecka/ dzieci' i w przyszłości, nie znając ograniczeń łączliwości, gdy zrodzi się potrzeba, samodzielnie konstruować takie połączenia, jak *szpital dziecinny.

Słownictwo staje się przestarzałe również pod wpływem przemian cywilizacyjnych. Te, zachodzące w świecie urządzeń elektronicznych, są dziś bardzo dynamiczne. Proces przygotowywania i wydawania podręcznika nie jest co prawda krótki, ale ucząc młodzież z podręcznika z 2006 czy 2008 roku, raczej trzeba się będzie od razu przygotować na objaśnienie desygnatów kasety i magnetowidu.

Z drugiej strony w podręcznikach zdarza się napotkać wyrazy, które odnoszą się do desygnatów ciągle mało typowych w obrębie pewnych kategorii, nienotowane w słownikach, o niejednoznacznym dla ogółu użytkowników języka polskiego odniesieniu pozajęzykowym. I tak, ponownie w podręczniku Jak to łatwo powiedzieć... (Gałyga, 2011: 79) wprowadzane są nazwy deserów. Wśród nazw typowych rodzajów ciastek i ciast, takich jak pqczki, sernik czy kremówka pojawiają się też oponki. Nazwa ta z pewnością nie należy do tradycyjnego polskiego słownictwa kulinarnego. Ciastka nazywa się tak ze względu na charakterystyczny kształt, ale metaforyczne rozszerzenie znaczenia słowa oponka nie wydaje się w polszczyźnie utrwalone, a i ścisłe odniesienie wyrazu nie tak oczywiste. Z wyrywkowego wywiadu, który przeprowadziłam w Gdańsku, by to zweryfikować, wynika, że jeśli słowo jest rozpoznawane w tego rodzaju znaczeniu (a częściej nie było), jest odnoszone do ciastka pączkowego, zwanego częściej donatem lub ptysiowego, zwanego zazwyczaj gniazdkiem. Niezależnie od tego, o który rodzaj ciastek chodzi, nie jest chyba jednak całkiem oczywiste, że

\footnotetext{
2 Już Słownik poprawnej polszczyzny PWN z 1980 r. notował to znaczenie wyrazu jako rzadsze (z przykładem pokój dziecinny).
} 
same desygnaty reprezentują ciastka tak typowe jak na przykład pączki, eklery czy pierniki. Swoją drogą użycie w podręczniku liczby mnogiej pq̨czki i oponki w zestawieniu z materiałem ikonograficznym, na którym prezentowane są pojedyncze ciastka, też nie może być pozostawione na lekcji bez komentarza. Typowo można się bowiem przy takim sposobie prezentacji spodziewać mianownika liczby pojedynczej, a na początkowym etapie nauki studenci nie są przygotowani, by samodzielnie rozpoznawać formę fleksyjną wyrazu wprowadzanego bez kontekstu.

Przykładów podobnych zjawisk można znaleźć w podręcznikach więcej. W Hurra!!! w lekcji wprowadzającej słownictwo kulinarne (Małolepsza i Szymkiewicz, 2006: 55) w menu restauracji są na przykład kotlety z tofu (tofu - twarożek z mleka sojowego, typowy dla kuchni Azji). Być może autorkom podręcznika przyświecała idea wywołania wrażenia ponadlokalności Polski, ale czy płynące z tego korzyści mogą przeważyć nad kłopotami, jakie wiążą się z wprowadzeniem wyrazu rzadkiego, oznaczającego desygnat niekoniecznie znany wszystkim, oraz z jednoczesnej utraty okazji do wprowadzenia w miejsce tego słowa innego: z tego samego zakresu tematycznego, ale częściej spotykanego?

Nieraz można się spotkać w podręcznikach z sytuacją, w której pojedynczym reprezentantem pewnej grupy tematycznej jest wyraz raczej chyba mniej przydatny w codziennej komunikacji niż inne z tego zakresu. Pojawiająca się w pierwszej lekcji Jak to łatwo powiedzieć... główna bohaterka studiuje etnografię. W ćwiczeniach w dalszej części podręcznika pojawiają się sporadycznie inne nazwy kierunków studiów, ale to właśnie ten jest powtarzany. W ostatniej lekcji wprowadza się większą grupę takich nazw z podziałem na rodzaje nauk. Wśród nauk medycznych jest dietetyka, ale nie medycyna, wśród społecznych europeistyka, ale nie prawo czy pedagogika. Podobnie, właśnie europeistykę, a nie inny kierunek studiuje pierwsza studentka, która pojawia się w podręczniku Hurra!!!

W podręczniku Jak to łatwo powiedzieć... w dialogu w sklepie mięsnym (Gałyga, 2011: 59), który jest okazją do zaprezentowania nazw wyrobów mięsnych, pojawiają się parówki, szynka, kiełbasa, skrzydełka z kurczaka, a obok nich karczek (chociaż to karkówka, nie karczek jest w słownikach definiowana jako rodzaj mięsa). W Hurra!!! pierwszą wprowadzoną nazwą instrumentu muzycznego (a nie są one w podręczniku prezentowane w grupie tematycznej, tylko kilka z nich pojawia się gdzieniegdzie w ćwiczeniach) (Małolepsza i Szymkiewicz, 2006: 37) jest saksofon. Co robi zaś dentysta, którego dzień opisuje podręcznik z poziomu A0 Start 1? O jedynej związanej z charakterem wykonywanej pracy czynności informują słowa: instaluje protezę (Dembińska i Małyska, 2010: 10.6) ${ }^{3}$.

\footnotetext{
${ }^{3} \mathrm{~W}$ podręczniku zastosowano nietypową numerację stron.
} 
W kognitywnym ujęciu relacji między leksemami należącymi do tej samej domeny pojęciowej zwraca się w uwagę na zjawisko wyrazistości, które odpowiada ogólnej zasadzie organizacji rzeczywistości przez ludzki umysł. I tak w obrębie domeny pojęciowej można mówić o poziomie ogólnym, podstawowym i szczegółowym. Do opisania zjawisk najczęściej wybierane są terminy z poziomu podstawowego, to one jako pierwsze przychodzą na myśl, w nich efekty wyrazistości są najbardziej widoczne. Poszczególne elementy kategorii z poziomu podstawowego posiadają wystarczająco dużo wspólnych cech, natomiast zasadniczo różnią się od elementów podstawowych innych kategorii (Tabakowska, 2001: 60-63) Można to zobrazować na przykładzie trzech wyrazów z tej samej domeny pojęciowej: zwierzę, pies, sznaucer. Pierwszy jest terminem poziomu ogólnego, drugi - podstawowego, trzeci-szczegółowego. Nie powiemy raczej: Słyszę, że gdzieś blisko szczeka jakieś zwierzę; U nas $w$ domu jest czworo ludzi i sznaucer, w tych kontekstach naturalnie wystąpi termin z poziomu podstawowego: pies.

W podręczniku Hurra!!! w lekcji tematycznie związanej z zakupami jest ćwiczenie wprowadzające podstawowe nazwy sklepów i produktów. Należy w nim do każdej nazwy sklepu dobrać 1 lub 2 produkty w nich kupowane. Dla kwiaciarni wybrano bukiety oraz róże i tulipany (Małolepsza i Szymkiewicz, 2006: 76). Kwiatek pojawia się 4 lekcje dalej, wraz z meblami, jako element charakterystyczny dla wystroju mieszkania. (ibid., 116). Podobnie w analogicznym ćwiczeniu w Jak to łatwo powiedzieć...(Gałyga, 2011: 67), w którym należy połączyć obrazek (róże w bukiecie), słowo bukiet i nazwę kwiaciarnia. A przecież trudno sobie wyobrazić, żeby ktoś zapytał na ulicy: Przepraszam, gdzie tu blisko mogę kupić bukiety/ róże?

Zasadą organizacji pojęciowej postrzeganej rzeczywistości jest też wyodrębnianie i postrzeganie najpierw przedmiotów czy istot ożywionych jako całości, potem dopiero ich części. W podręczniku Dzień dobry!, zupełnie na marginesie jednej z lekcji i poza treściowym z nią związkiem (Janowska i Pastuchowa, 2008: 43), jest rysunek ryby mówiącej: Jestem niebieska, mam niebieskie płetwy, chociaż nie pojawiło się wcześniej słowo ryba. Oczywiście, ponieważ pojawienie się rysunku zazwyczaj skłania do językowego komentarza, można liczyć na to, że zrobi to w tym miejscu nauczyciel (wahając się dodatkowo, czy nie wspomnieć o ogonie, ważniejszym chyba od płetw, bo ma go większa liczba zwierząt).

Swoją drogą samo definiowanie ostensywne w podręcznikach bywa też dla nauczyciela źródłem kłopotów. Garderoba jako pomieszczenie (skądinąd takie znaczenie wyrazu opatrywane jest w słownikach kwalifikatorem ksiqżkowe lub przestarzałe) jest pokazana na rysunku jako obszerny, przechodni hol z jedną szafą, choć nie jest do końca jasne, czy czasem nie odnosi się do samej 
tej wolno stojącej szafy. Pokój dziecinny, w którym jest wyłącznie łóżko i kwiatek, należy odróżnić od identycznie narysowanej, tylko z łóżkiem podwójnym i małym stolikiem, sypialni oraz w pełni umeblowanego pokoju gościnnego. Łóżko, umieszczone w salonie, obrazowane jest jako typowa kanapa (Gałyga, 2011: 97, 103).

Odwieczny problem przy porządkowaniu i selekcjonowaniu materiału leksykalnego w nauczaniu języka obcego stanowią synonimy. W miarę nauki, przechodząc na coraz wyższe poziomy zaawansowania języka, student zaczyna poznawać wyrazy bliskoznaczne w stosunku do już poznanych, ale słownictwo na początku nauki powinny budować raczej pojedyncze wyrazy reprezentujące dane znaczenie, najszersze znaczeniowo, o najczęstszej frekwencji, student ma bowiem jeszcze przed sobą wymagające dużego wysiłku zadanie poznania wielotysięcznego zbioru leksemów. Czy zatem jest bardzo potrzebne, by na początkowym etapie nauki prezentować zarówno wyraz pływalnia, jak i basen (Małolepsza i Szymkiewicz, 2006: 46, 48, 61), parasol i parasolka, w wyglądzie takie same, ten pierwszy z przeznaczeniem dla mężczyzny, drugi dla kobiety (Janowska i Pastuchowa, 2008: 17)? Zlewozmywak czy zlew? Klozet, sedes, ubikacja czy wc? Pływać na kajaku czy pływać kajakiem? Mimo pomocy słowników i korpusów językowych nie zawsze łatwo jest podjąć decyzję, opierają się one bowiem na materiale bardzo szerokim, zróżnicowanym pod względem stylowym i chronologicznym, tymczasem w podręczniku chodzi o wyraz, z którym najczęściej w swojej rzeczywistości spotka się student i który będzie najprzydatniejszy do jego potrzeb komunikacyjnych, ewentualnie - w wypadku konstrukcji składniowej - o taką, która będzie najlepiej reprezentować jakąś ich grupę. Co dla rodzimego użytkownika języka wydaje się rzeczą, nad którą nie ma się co zbyt długo zastanawiać, w podręczniku do nauki języka jako obcego ma zupełnie inną wagę. To decyzja autorów o daniu wyrazowi szansy na to, by był zapamiętany, na długo albo być może w ogóle jako jedyny z grupy. Własne przyzwyczajenia językowe, zarówno autora podręcznika, jak i korzystającego z tego podręcznika nauczyciela, na pewno powinny być poddane rygorom myślenia w tych kategoriach.

\section{Problemy związane z kontekstem językowym wprowadzanego słownictwa}

Przy założeniu, że sprawność komunikacyjna jest priorytetem w nauczaniu języka, wprowadzeniu wyrazów powinna towarzyszyć prezentacja kontekstu, w jakim on występuje czy też może przykładowo wystąpić w języku. W Jak to łatwo powiedzieć... (Gałyga, 2011: 44) wprowadza się przyimki określające lokalizację, w jednej grupie z określeniami kierunku (typu prosto) i położenia (typu po lewej stronie). Tylko częściowo pojawiły się one we wcześniejszym dialogu opartym na sytuacji wskazywania drogi w mieście. W ćwiczeniu należy je połączyć 
z obrazkami, których centralną postacią jest kot, usytuowany przestrzennie na tle innych elementów. Przy założeniu, że składnikiem kompetencji leksykalnej jest też umiejętność użycia wyrazu w poprawnych konstrukcjach składniowych i znajomość kolokacji wyrazu (Seretny i Lipińska, 2005: 76-77), trzeba uznać, że daje to studentowi zasadniczo tylko możliwość włączenia tych leksemów do słownictwa biernego, gdyż przyimki te łączą się z różnymi przypadkami (dopełniaczem lub narzędnikiem), a określenia związane z kierunkiem - z różnymi czasownikami.

Innym z kolei problemem jest podawanie nienaturalnych kontekstów językowych. W podręczniku można spotkać polecenia formułowane w następujący sposób: Proszę czytać/ słuchać/ numerować/ mówić/ literować/ pisać (Start 1, Dzień dobry!). Można się domyślać, że cel, jaki w tym wypadku przyświecał autorom, to właśnie wprowadzenie wyrazu podstawowego w sensie słowotwórczym, będącego bazą derywacyjną dla całej grupy innych wyrazów, jednocześnie mniej złożonego formalnie. Jednak naturalne $w$ języku jest użycie w takim kontekście czasownika o aspekcie dokonanym i mało prawdopodobne, by jakakolwiek przypadkowa osoba, która ewentualnie mogłaby takie polecenie wydać, dokonała na użytek lepszej komunikacji z cudzoziemcem natychmiastowej analizy problemu językowego i w efekcie zdecydowała się na użycie słowa, z którym, jak mogłaby podejrzewać, zetknął się on jako z bardziej podstawowym. Jeśli zaś do tego nie dojdzie, to z kolei rodzi się pytanie, czy początkujący student, usłyszawszy np. słowo przeliterować, od razu rozpozna i właściwie oceni jego semantyczny związek z poznanym wcześniej wyrazem literować.

\section{Wprowadzanie słownictwa motywowane względami dodatkowymi a kwestie metodyczne}

Z kolei niezwiązane bezpośrednio z dydaktyką względy - chęć wprowadzenia do lekcji elementów humoru - wydają się stać u podstaw niektórych innych, wywołujących kolejne kłopotliwe sytuacje, decyzji leksykalnych. Do takich należy niewątpliwie tekst, którego bohaterem jest Mikołaj Brzęczuszczyński z Hurra!!! (Małolepsza i Szymkiewicz, 2006: 130). Tekst jest co prawda zamieszczony dopiero w lekcji 16 spośród 20, na które podzielony jest podręcznik, kiedy, jak można przypuszczać, studenci są już bardziej oswojeni z fonetyką niż na samym początku, ale z pewnością jest to najtrudniejszy pod względem fonetycznym wyraz w całym podręczniku. W Dzień dobry! nazwisko Brzęczykowie pojawia się jednak już na samym początku podręcznika - w lekcji 3 na ich ogólną liczbę 48 (Janowska i Pastuchowa, 2008: 11), chociaż przyznać trzeba, że w tym podręczniku fonetyka jest już na samym początku ćwiczona na trudnym, choć niewątpliwie przydatnym, materiale nazw polskich miast i miejscowości. 
Nazwy własne wydają się zresztą swoistym polem żartu językowego w podręcznikach, na którym to polu rygorystyczne myślenie o celach nauczania jest osłabione. Nie zawsze jednak ten żart będzie mógł samodzielnie rozpoznać student, bo często wymaga to większej biegłości językowej niż ta, którą można przewidywać na danym poziomie. I tak biuro tłumaczy nosi nazwę Czeski bład, biuro księgowe Pieniq̨dze szczęścia nie dajq (Janowska i Pastuchowa, 2008: 169), centrum handlowe zaś - Mamona (Małolepsza i Szymkiewicz, 2006: 76), kierujący list do reakcji podpisują się jako Pytajscy (ibid., 121). Nauczyciel stoi w tym wypadku przed dylematem: „Uznać całkowicie deiktyczny charakter nazw własnych, pozostawiając je bez komentarza, czy tłumaczyć źródła komizmu?". W podręcznikach pojawiają się też nazwiska i nazwy odapelatywne - wcześniej niż apelatywy, od których zostały utworzone: Kiełbasa, Styczeń, Blask, Lampart (Małolepsza i Szymkiewicz, 2006: 12, 75; Dembińska i Małyska, 2010: 7.12, 8.07).

Podobny dylemat budzą nazwa mydła Czyste ręce i pasty do zębów Biały uśmiech (Gałyga, 2011: 63). Tłumaczyć nazwę czy nie i dodatkowo - czy komentować ją na tle realiów nazewniczych, zwłaszcza że w dialogach wcześniejszych lub późniejszych pojawiają się nazwy autentycznych lekarstw na przeziębienie czy popularnej polskiej kiełbasy? Takiego wyjaśniającego komentarza wymagałoby już chyba na pewno nagłe pojawienie się niepolskiego imienia w szeregu: Matylda Morska, Saida Siczek, Alicja Kamińska (Gałyga, 2011: 170), zanim uczniowie nabiorą przekonania, że Saida to typowe albo przynajmniej dość popularne polskie imię.

Innego typu problem wiąże się z kolei z próbą dochowania wierności realiom $\mathrm{w}$ nazewnictwie. $\mathrm{W}$ jednym $\mathrm{z}$ dialogów w podręczniku Jak to łatwo powiedzieć... jego bohaterka, Amerykanka polskiego pochodzenia o nazwisku Kate Jankowski rozmawia z mamą Krystynq Jankowski (Gałyga, 2011: 98). Wybranie dla bohaterki nazwiska typowo polskiego, podlegającego regułom fleksyjnym, w postaci unieruchomionej fleksyjnie, jak dzieje się w przypadku funkcjonowania go w systemie języka analitycznego, jakim jest angielski, wymaga już z pewnością obszerniejszego komentarza, ponieważ przymiotnikowa postać nazwiska jest na tyle dla języka polskiego typowa, że wręcz nie sposób sądzić, iż studenci mogliby się dalej z takiego rodzaju nazwiskami nie zetknąć.

Perspektywiczne myślenie o celach nauczania w zakresie słownictwa jest jednak najbardziej osłabione w przypadku materiału, który posłużyć ma do ćwiczenia fonetyki bądź prezentować jakieś prawidła gramatyczne. W Hurra!!! w 2 lekcji zaraz po wprowadzeniu podstawowego słownictwa służącego opisowi cech fizycznych pojawia się ćwiczenie, którego celem jest zaprezentowanie akcentu w polszczyźnie (Małolepsza i Szymkiewicz, 2006: 20). Wyrazy, na których przykładzie należy to obserwować, stanowią jednolitą semantycznie grupę nazywają cechy 
osobowości bądź stany psychiczne. Z uwagi na cel ćwiczenia zostały wybrane wyrazy długie, wielosylabowe, ułatwieniem dla studenta ma być to, że są to w większości internacjonalizmy. Są wśród nich przykładowo leksemy kreatywny, emocjonalny, zestresowany, spontaniczny, energiczny czy aktywny. Materiał ten bywa jednak częściowo wykorzystany w ćwiczeniach późniejszych, w których konstruuje się zdania egzystencjalne o nietypowej treści w rodzaju: Roman jest energicznym Polakiem, Jestem młodym i aktywnym Polakiem z Krakowa (ibid., 27). W podręczniku nie jest już dalej wprowadzane inne słownictwo dotyczące cech charakteru człowieka, na tym etapie podany zestaw w całości konstytuuje zasób słów studenta z tego zakresu tematycznego. W innym miejscu ćwiczenie wymowy wymaga rozpoznania słyszanych wyrazów. Na 20 podanych wyrazów 19 to nazwy dziedzin wiedzy lub kierunków studiów, a tylko jeden jest spoza tego zakresu tematycznego: galeria (ibid., 44). W podręczniku Start 1 - będącym kursem wstępnym do nauki języka - w każdej lekcji obszerne miejsce zajmują ćwiczenia fonetyczne, których celem jest różnicowanie określonych głosek. Materiał leksykalny, który został dobrany dla realizacji tego celu, zawiera przykładowo takie leksemy jak: wałek, tren, weksel, wena, ławica, kiść, boczniak, puce, sęk, cyrylica, carewicz, pędy, fuzja, żelaźniak, uzda, widły, czczy, wielebny, rozmach, szałwia, żołd, rozrzedzony, gwieździsty, derywaty: szacuneczek, wqsisko, garstka, niepodstawowe formy fleksyjne: blokował, doi, flądro, renetę, drętwej, gaże, szlocha, lotkq, koci, czytajq̨c. Są to wyrazy zupełnie nieodpowiadające poziomem materiałowi leksykalnemu i gramatycznemu wprowadzanemu na lekcjach, najwyraźniej ujmowane wyłącznie w postaci fonetycznej, którą student ma wyłącznie odtworzyć bądź rozpoznać ze słuchu.

Nieco większa dbałość o zsynchronizowanie materiału z poziomem zaawansowania charakteryzuje ćwiczenia gramatyczne, ale i tu nauczyciel staje wobec problemu wyjaśnienia znaczenia i użycia, bądź całkowitej z tego rezygnacji, w przypadku takich leksemów wybranych do prezentacji modelu odmiany czasowników zakończonych na -ować, jak kreować czy koniugować (Małolepsza i Szymkiewicz, 2006: 48; Dembińska i Małyska, 2010: 10.08). Wybrane są one bowiem według kryterium skojarzeń ze słowami podobnie brzmiącymi w innych językach, a nie na zasadzie frekwencji w polskich tekstach (ten sam model odmiany ma np. częsty frekwencyjnie, przydatny komunikacyjnie wyraz malować), co być może jest pewnym ułatwieniem dla studentów anglojęzycznych, ale już nie azjatyckich. Próba pokazania w podręczniku ich użycia w zdaniach przynosi takie ich propozycje, jak np. Ja koniuguję czasowniki (Małolepsza i Szymkiewicz, 2006: 48). 


\section{Kiedy autor traci czujność, czyli błędy w podręcznikach}

Zdarzają się także wyrazy błędne czy błędnie użyte, które już ewidentnie wymagają komentarza sprostowującego. W Start 1 pojawiają się na przykład jako nazwy liter alfabetu ci oraz źet (Dembińska i Małyska, 2010: 1.07). W Jak to łatwo powiedzieć... pojawia się konstrukcja może spotykana często w Polsce południowej czy zachodniej, ale nieustannie piętnowana w wydawnictwach poprawnościowych, nieakceptowana przez normę językową - ubrać cośs (w znaczeniu 'włożyć ubranie': Myślę, że powinnaś ubrać/ założyć na siebie...(Gałyga, 2011: 147).

\section{Wnioski}

Analiza problemów leksykalnych, z jakimi spotyka się korzystający ze współczesnych podręczników nauczyciel języka polskiego jako obcego, skłania do wniosku, że dobór leksykalny materiału w nauczaniu języka jako obcego jest rzeczą, której poświęcić należy więcej skoncentrowanej uwagi i namysłu teoretycznego. Postulat oparcia się na danych frekwencyjnych, łatwiejszy dziś do zrealizowania z uwagi na powszechną dostępność do korpusów językowych, musi iść w parze z kognitywną refleksją nad reprezentowaniem przez wyrazy rzeczywistości myślowej, jej kategoryzowaniem i zhierarchizowaniem, a własne wyczucie językowe autorów, kształtowane często przez wpływy regionalne, weryfikowane powinno być na podstawie wydawnictw poprawnościowych stanowiących zapis normy ponadregionalnej. Potrzebna jest też rygorystyczna dyscyplina myślenia i planowania umożliwiająca panowanie nad całością materiału prezentowanego w podręczniku, nad budowaniem i rozszerzaniem kręgów tematycznych słownictwa. Należy też w miarę możliwości starać się aktualizować materiał leksykalny w kolejnych wydaniach podręczników. Słowo zapisane w podręczniku dla obcokrajowca ma bowiem inną wagę niż słowo w podręczniku dla rodzimego użytkownika języka, który dysponuje ogromnym kontekstem słów i tekstów pochodzących spoza tego podręcznika, i w życiu przeczytanych, i usłyszanych, i który ma inną niż cudzoziemiec świadomość realiów kraju oraz środowiska, w których się tego języka naturalnie używa.

\section{BIBLIOGRAFIA}

Bańko, M. (red.). 2000. Inny słownik języka polskiego PWN. T. 1-2. Warszawa: Wydawnictwo Naukowe PWN.

${ }^{4}$ Zob. Doroszewski, 1980: 809; Markowski, 1999: 1081; Bańko i Krajewska, 1994: 333. 
Bańko, M., Krajewska, M. 1994. Słownik wyrazów kłopotliwych. Warszawa: Wydawnictwo Naukowe PWN.

Dembińska, K., Małyska, A. 2010. Start 1. Survival Polish. Podręcznik do nauki języka polskiego na poziomie AO. Warszawa: Klub Dialogu S.C.

Doroszewski, W. (red.). 1980. Słownik poprawnej polszczyzny PWN. Warszawa: Państwowe Wydawnictwo Naukowe.

Dubisz, S. (red.). 2008. Uniwersalny słownik języka polskiego. T. 1-4. Warszawa: Wydawnictwo Naukowe PWN.

Gałyga, D. 2011. Jak to łatwo powiedzieć... Ćwiczenia komunikacyjne dla poczq̨tkujqcych. Kraków: Towarzystwo Autorów i Wydawców Prac Naukowych Universitas.

Janowska, A., Pastuchowa, M. 2008. Dzień dobry! Podręcznik do nauki języka polskiego dla poczq̨tkujqcych. Tarnów: Tarnowska Fundacja Kultury.

Małolepsza, M., Szymkiewicz, A. 2006. Hurra!!! Po polsku 1. Podręcznik studenta. Kraków: PROLOG Szkoła Języków Obcych.

Markowski, A. (red.). 1999. Nowy słownik poprawnej polszczyzny PWN. Warszawa: Wydawnictwo Naukowe PWN.

Seretny, A., Lipińska, E. 2005. ABC metodyki nauczania języka polskiego jako obcego. Kraków: Universitas.

Tabakowska, E. (red. ). 2001. Kognitywne podstawy języka i językoznawstwa. Kraków: Towarzystwo Autorów i Wydawców Prac Naukowych Universitas.

http://ogloszenia.trojmiasto.pl DW 05.09.2014.

http://www.ogloszenia.krakow.pl DW 06.09.2014. 